\title{
Replacement of soybean meal with sunflower one in the diet of broiler chickens and its influence on their growth and development
}

\author{
Havilei O. ${ }^{1}$, Pankova S. ${ }^{2}$, Katerynych O. ${ }^{3}$, Poliakova L. ${ }^{4}$ \\ State Poultry Research Station of NAAS \\ 20 Tsentralna Str., Borki vill., Zmievsky district, Kharkiv oblast, 63421, Ukraine \\ e-mail: ${ }^{1} e l e n a . g a v i l e y @ g m a i l . c o m, ~{ }^{2}$ svet_my@ukr.net, ${ }^{3}$ katerinich@ukr.net, ${ }^{4} /$ luda.polyakova@ukr.net \\ ORCID: ${ }^{1}$ 0000-0003-3635-0777, ${ }^{2} 0000-0001-7504-9878,{ }^{3} 0000-0003-4865-2238,{ }^{4} 0000-0003-2235-7062$
}

Goal. To analyze the influence of replacement of soy with protein sunflower concentrate in the diets for broiler chickens and to evaluate the effect of this ingredient on the growth and development of poultry. Methods. The experiment was conducted on broiler chickens of cross Cobb 500 for fattening from 1-day age to 42-days age. 3 groups of 50 chickens were formed, which were fed with rations where soy components were replaced with protein sunflower concentrate at the levels: $0 \%$ (control group), $45 \%$ (experimental group 1), and $70 \%$ (experimental group 2). Feed consumption and bird death were recorded daily, and the live weight of the bird was monitored weekly. At the end of the experiment, the slaughter qualities of broilers were evaluated. Results. The addition of protein sunflower concentrate to the diets of broiler chickens (crude protein level - 44.4\%) did not negatively influence their growth and development, but on the contrary, increased the final live weight by $20.3 \%$ (experimental group 2). Replacement of soybeans with this ingredient at the level of $45 \%$ (experimental group 1) did not significantly affect feed conversion, live weight dynamics, and slaughter qualities of chickens. Increasing the level of replacement to $70 \%$ (experimental group 2) contributed to the improvement of poultry productivity - the average daily increase in live weight exceeded this index in other groups by $19.4-20.9 \%$. The yield of the gutted carcass in the group with $70 \%$ soybean substitution for sunflower was $5.5 \%$ higher than in the control (without sunflower) and in the experimental group 1 (45\% soybean replacement with sunflower) $-73.1 \%$, against $67.6-67.7 \%$. Feed costs per $1 \mathrm{~kg}$ of growth in the experimental group 2 were lower by $14.8-15.3 \%(1.61 \mathrm{~kg})$. The meat productivity index for the diet with a 70\% replacement of soy with sunflower protein concentrate was 322.5 . Conclusions. Taking into account productivity indicators (increase in live weight and intensity of its growth, improved feed conversion, increased gut carcass yield) and technological efficiency of fattening, it is recommended to replace up to $70 \%$ of soy components with protein sunflower concentrate in broiler diets.

Key words: poultry feeding, protein sunflower concentrate, live weight, meat productivity index.

DOI: https://doi.org/10.31073/agrovisnyk202012-05

The main reserve for reducing the cost of feed, and, accordingly, the cost of livestock products, is the reduction in the cost of the protein component of the diet. An alternative to traditional, expensive poultry feeds can be cheaper, more affordable and nutritious substitutes - agricultural by-products. Recently, the world began to use sunflower processing products as an alternative source of protein in poultry diets and replace soybean meal with them [1].

Sunflower processing products, which are produced in sufficient quantities in all climatic zones of Ukraine, are the largest source of feed protein. According to physiological experiments, it was found that for broiler chickens the energy value of this product ranged from $218.5-284.2 \mathrm{kcal} / 100 \mathrm{~g}$ [2]. Unfortunately, a number of factors, namely: insufficient complete protein, significant excess of fiber, low content of some essential amino acids, in particular lysine, the ability to accumulate chlorogenic acid, limit the use of sunflower in animal feeding [3].

At the same time, the main and decisive factor in the use of sunflower processing products in animal husbandry is the reasonable price of oilseed feed protein. In addition, technologies for enrichment of sunflower meal have been developed, which allow increasing the protein level to $40-44 \%$, and reducing the fiber level to $8-10 \%$. With such a dramatic improvement in nutritional value, the cost of the supplement will increase by only $20-40 \%$ [4].

One of the leading producers of sunflower meal in Ukraine - the Potoki oil extraction plant (Dnipro), using modern technology for additional mechanical processing of this product, produces high-protein sunflower concentrate, which significantly differs from the original meal in terms of protein and energy nutritional value (the manufacturer declared the level of crude protein $-44.4 \%$, metabolizable energy $-228 \mathrm{kcal} / 100 \mathrm{~g}$ ).

Taking this into account, sunflower protein is now considered all over the world as the main means of enriching the diet of pigs, livestock, and poultry with crude protein [5 - 7]. However, there is still no consensus on the levels of addition of these products to poultry feed.

In laying hens receiving feed, where the level of sunflower meal was $20 \%$, there was no significant effect on egg production, egg weight and quality, as well as the antioxidant status of poultry, but feed consumption decreased. Therefore, the authors suggest that partial or complete replacement of soybean meal with this 
product will reduce production costs. Moreover, feeding the laying hens with feed with the addition of sunflower reduces the cholesterol content in the yolk of eggs [8].

At the same time, studies on turkeys during rearing for meat indicate that the presence of sunflower meal at the level of $7 \%$ in the diets did not have a negative effect on the digestibility of feed nutrients, the physiological state of the bird and its live weight. A twofold and threefold increase in the concentration of this product led to a decrease in the live weight of turkeys at the age of 8 weeks by 4 and $6 \%$, respectively [9].

In experiments on waterfowl [10], it was recorded that live weight, feed conversion, as well as egg production of geese and ducks did not change significantly even with $100 \%$ replacement of soybean meal with sunflower meal, but subject to the addition of synthetic amino acids and energy supplements.

Most studies on broilers indicate that sunflower meal may well be an alternative to soy in poultry diets, since it does not negatively affect their performance and physiological state. In the experiments of Sangsoponjit et al. [11] the addition of sunflower meal to feed at the level of $4 \%, 8 \%$ and $12 \%$ did not affect live weight, feed consumption and its conversion and broiler safety. The same applies to carcass yield and abdominal fat. The best European Broiler Efficiency Index was obtained for the addition of $8 \%$ sunflower meal to the diet.

The research results Alagawany et al. [12] show that sunflower meal can be advantageously used up to $20 \%$ instead of soybean meal without significantly affecting the growth rate of broiler chickens, their consumption of feed and its conversion.

In other studies, when assessing the effect of replacing soybean meal with sunflower at the level of $25 \%$, $50,75 \%$ on the growth rates of broilers, their meat quality and their absorption of nutrients, it was found that increasing the level of substitution up to $50 \%$ also increased the live weight of chickens. There was also an improvement in feed conversion in the groups receiving the diet with 25 and $50 \%$ substitution of soybeans for sunflower compared to the control. The authors recommend the use of up to $50 \%$ sunflower meal in the diets of broilers aged 7 - 42 days without the use of additional enzymes [13].

Waititu et al. [14] also found that high-protein sunflower meal can be substituted for up to $50 \%$ of soybean meal in broiler chickens' diets without deteriorating growth performance in both the initial and final phases. When replacing $75 \%$ of the soybeans, the authors believe that adding enzymes is beneficial; this may alleviate the growth depression associated with feeding.

In a similar experiment, raising the level of sunflower meal in the diets to $50 \%$ instead of soybean meal improved the growth performance of broilers. An even higher level of sunflower (75\%) improved nutrient absorption but negatively affected growth performance and feed utilization in birds [15]. So, there is no unanimous judgment regarding the levels of sunflower-soy substitution in broiler feed.

Therefore, our research was aimed at analyzing the possible levels of replacement of soybean meal in broiler chicken diets with protein sunflower concentrate without compromising the productivity and safety of the poultry.

The goal of the study was to determine the effect of protein sunflower concentrate on the growth and development of broiler chickens at different levels of its feeding in the feed.

Materials and research methods. The study was conducted at the experimental farm "Conservation of the gene pool of domestic birds" State Poultry Research Station HAAH on broiler chickens Cobb 500. From day-old birds 3 randomized groups of 50 birds each were formed (table. 1).

\section{Scheme of the experiment on feeding the protein sunflower concentrate to broiler chickens}

\begin{tabular}{|l|l|}
\hline \multicolumn{1}{|c|}{ Bird group } & \multicolumn{1}{c|}{ Feeding characteristic } \\
\hline Control (C) & $\begin{array}{l}\text { Basic feed with the addition of soy components: 35\% from the 1st to the 10th day of } \\
\text { growing, 32\% - from the 11th to the 24th day, 27\% - from the 25th to the 42nd day }\end{array}$ \\
\hline $\begin{array}{l}\text { Experimental 1st } \\
\text { (E1) }\end{array}$ & $\begin{array}{l}\text { Feed with the replacement of soy components with protein sunflower concentrate: } \\
\text { - from the 25th to 42nd day (on average for the growing period, the replacement of } \\
\text { soybeans with sunflower is 45\%) }\end{array}$ \\
\hline $\begin{array}{l}\text { Experimental 2nd } \\
\text { (E2) }\end{array}$ & $\begin{array}{l}\text { Feed with replacement of soy components with protein sunflower concentrate: 14\% } \\
\text { from 1st to 10th days of growing, 45\% from 11th to 24th days, 90\% from 25th to 42nd } \\
\text { days (on average, replacement of soybeans with sunflower during the growing period } \\
\text { is 70\%) }\end{array}$ \\
\hline
\end{tabular}

One of the groups was the control group (C), in which the chickens received feed based on soybean meal and meal without the addition of sunflower, the other 2 - experimental groups (E1 and E2), in which the 
chickens were fed food with different levels of replacement of soy components with protein sunflower concentrate produced Potoki Ltd. Therefore, 3 experimental diets were formed, which included protein sunflower concentrate as a substitute for soy components at the levels of $0 \%, 45$ and $70 \%$. Experimental diets were isoenergetic and isoprotein, balanced in all nutrients, free of feed antibiotics and other growth stimulants and depended on the phase of development of the birds (Table 2). With an increase in the amount of sunflower concentrate in the diet, lysine was additionally introduced, which is not enough in this product.

\section{Ingredients and nutritional value of experimental diets for broiler chickens according to age}

\begin{tabular}{|c|c|c|c|c|c|c|c|c|c|}
\hline \multirow{3}{*}{ Indicators } & \multicolumn{9}{|c|}{ Poultry group depending on the level of soybean substitution PSC ${ }^{1}$} \\
\hline & \multicolumn{3}{|c|}{ start (1-10 days) } & \multicolumn{3}{|c|}{ growth (11-24 days) } & \multicolumn{3}{|c|}{ finish (25-42 days) } \\
\hline & $\mathrm{C}$ & E1 & E2 & C & E1 & E2 & C & E1 & E2 \\
\hline \multicolumn{10}{|c|}{ Content of dietary components, $\%$} \\
\hline Wheat & 10 & 10 & 10 & 10 & 10 & 10 & 7.9 & 8.5 & 8.6 \\
\hline Corn & 45 & 45 & 45 & 52.4 & 52.5 & 52.5 & 60 & 60 & 60 \\
\hline Soybean cake & 10 & 10 & 10 & 20 & 20 & 16.2 & 25.3 & 9.9 & 0 \\
\hline Soybean meal & 24.9 & 19.6 & 19.6 & 12.3 & 1.7 & 0 & 1.7 & 0 & 0 \\
\hline $\mathrm{PSC}^{1}$ & 0 & 5 & 5 & 0 & 10 & 15 & 0 & 15 & 23.8 \\
\hline Bone flour & 0 & 0 & 0 & 0.13 & 0 & 0 & 0 & 0 & 0 \\
\hline Fish flour & 5.04 & 5.03 & 5.03 & 0 & 0 & 0 & 0 & 0 & 0 \\
\hline Meat and bone meal & 3 & 3 & 3 & 3 & 3 & 3 & 2.5 & 2.51 & 2.5 \\
\hline Sunflower oil & 1.2 & 1.45 & 1.45 & 1.16 & 1.6 & 1.99 & 1.43 & 2.8 & 3.66 \\
\hline Lysine & 0.22 & 0.29 & 0.29 & 0.23 & 0.38 & 0.46 & 0.21 & 0.44 & 0.58 \\
\hline Methionine & 0.32 & 0.3 & 0.3 & 0.29 & 0.25 & 0.23 & 0.24 & 0.19 & 0.16 \\
\hline Threonine & 0.12 & 0.13 & 0.13 & 0.11 & 0.13 & 0.14 & 0.07 & 0.12 & 0.14 \\
\hline Salt & 0 & 0 & 0 & 0.08 & 0.04 & 0.08 & 0.11 & 0.1 & 0.12 \\
\hline a piece of chalk & 0 & 0 & 0 & 0.1 & 0.2 & 0.2 & 0.17 & 0.17 & 0.17 \\
\hline Monocalcium Phosphate & 0 & 0 & 0 & 0 & 0 & 0 & 0.17 & 0.07 & 0.07 \\
\hline $\begin{array}{l}\text { A mixture of vitamins and } \\
\text { minerals }\end{array}$ & 0.2 & 0.2 & 0.2 & 0.2 & 0.2 & 0.2 & 0.2 & 0.2 & 0.2 \\
\hline \multicolumn{10}{|c|}{ Nutritional value of feed } \\
\hline $\begin{array}{l}\text { Exchange energy, } \\
\text { kcal } / 100 \mathrm{~g}\end{array}$ & 300 & 300 & 300 & 310 & 310 & 310 & 320 & 320 & 320 \\
\hline Crude protein, $\%$ & 24.4 & 24.4 & 24.4 & 21.5 & 21.5 & 21.5 & 19.3 & 19.3 & 19.3 \\
\hline Crude fat $\%$ & 5.06 & 5.33 & 5.33 & 5.42 & 5.9 & 6.1 & 6.08 & 6.68 & 7.03 \\
\hline Crude fiber, $\%$ & 3.53 & 3.59 & 3.59 & 3.35 & 3.48 & 3.58 & 3.00 & 3.32 & 3.51 \\
\hline Calcium & 1.22 & 1.22 & 1.22 & 0.88 & 0.88 & 0.88 & 0.80 & 0.78 & 0.78 \\
\hline Phosphorus assimilable & 0.59 & 0.59 & 0.59 & 0.44 & 0.43 & 0.44 & 0.42 & 0.42 & 0.43 \\
\hline Linoleic acid & 2.09 & 2.26 & 2.26 & 2.43 & 2.74 & 2.9 & 2.83 & 3.34 & 3.65 \\
\hline Lysine & 1.28 & 1.28 & 1.28 & 1.15 & 1.15 & 1.15 & 1.01 & 1.01 & 1.01 \\
\hline Methionine & 0.65 & 0.65 & 0.65 & 0.58 & 0.57 & 0.57 & 0.51 & 0.52 & 0.52 \\
\hline Methionine + cystine & 0.95 & 0.95 & 0.95 & 0.87 & 0.87 & 0.87 & 0.79 & 0.79 & 0.79 \\
\hline Threonine & 0.86 & 0.86 & 0.86 & 0.77 & 0.77 & 0.77 & 0.67 & 0.67 & 0.67 \\
\hline
\end{tabular}

${ }^{1} \mathrm{PSC}$ - protein sunflower concentrate

The poultry was raised for 42 days with floor keeping and free access to water and feed in compliance with the recommended technological parameters. Chickens were vaccinated against Marek and Gumboro disease at one day of age, against Newcastle disease on time in the first rearing period.

Control weighing of chickens was carried out weekly in the context of groups. The amount of given feed and its residues were weighed daily, and the mortality of the bird was also taken into account. As a result, the dynamics of the live weight of chickens, its growth over the rearing periods, as well as the feed costs per 
head and $1 \mathrm{~kg}$ of live weight gain, and the safety of poultry in each group were assessed. At the end of the experiment at the age of 42 days, five birds from each group were selected at random for slaughter and carcass evaluation, the carcass yield was calculated as a percentage of the pre-slaughter weight of broilers.

Based on the results of the experiment, we calculated the efficiency of using compound feeds in feeding broiler chickens with a partial replacement of soy components with protein sunflower concentrate using the European index of meat productivity, which reflects such important indicators as live weight, safety and feed costs, according to the formula:

$$
E I M P=\frac{L W \cdot S \cdot 100}{D G \cdot F C}
$$

where EIMP is the European index of meat productivity, points; LW - average live weight, kg; $\mathrm{S}$ - safety of livestock, \%; DG - duration of growth, days; FC - feed costs per $1 \mathrm{~kg}$ of gain, $\mathrm{kg}$.

All data obtained were statistically processed, the difference between the diets was determined using the Tukey test.

Results and its discussion. In the course of the research, it was found that the safety of the livestock for 42 days in the control and the E2 group was equally high and amounted to $98 \%$, in the E1 group this indicator was $92 \%$. However, the reasons for this difference (trauma, Marek's disease) were not related to the subject of the experiment.

The obtained weighing data indicate that the replacement of soy components with protein sunflower concentrate contributed to a significant increase in comparison with the control of the live weight of broilers in both groups receiving a diet with this component, in the first period (1-3 weeks) - by 6.6-15.7\% in the group E1 and $10.1-25.8 \%$ in the group E2 (Table 3).

\section{Dynamics of live weight of broiler chickens at different levels of use in the diet of sunflower concentrate, $g$}

\begin{tabular}{|l|c|c|c|}
\hline \multirow{2}{*}{$\begin{array}{c}\text { Poultry age } \\
\text { weeks }\end{array}$} & \multicolumn{2}{|c|}{ Poultry group depending on the level of soybean substitution PSC } \\
\cline { 2 - 4 } & $\mathrm{C}(0 \%)$ & $\mathrm{E} 1(45 \%)$ & $\mathrm{E} 2(70 \%)$ \\
\hline day & $51.2 \pm 0.54$ & $50.7 \pm 0.58$ & $50.9 \pm 0.51$ \\
\hline 1 & $159.8 \pm 2.23$ & $170.3 \pm 2.56^{\mathrm{b}}$ & $176.0 \pm 2.33^{\mathrm{c}}$ \\
\hline 2 & $387.8 \pm 8.40$ & $430.2 \pm 9.83^{\mathrm{b}}$ & $468.6 \pm 8.85^{\mathrm{c}}$ \\
\hline 3 & $694.1 \pm 15.97$ & $802.9 \pm 16.71^{\mathrm{c}}$ & $873.1 \pm 23.12^{\mathrm{c}}$ \\
\hline 4 & $1150.1 \pm 30.45$ & $1167.7 \pm 27.75^{\mathrm{a}}$ & $1249.9 \pm 31.58^{\mathrm{c}}$ \\
\hline 5 & $1490.3 \pm 41.89$ & $1497.3 \pm 39.47$ & $1756.5 \pm 50.22^{\mathrm{c}}$ \\
\hline 6 & $1846.8 \pm 46.74$ & $1869.8 \pm 27.31^{\mathrm{a}}$ & $2221.9 \pm 58.21^{\mathrm{c}}$ \\
\hline
\end{tabular}

a, b, c - reliably when comparing the control and experimental groups: $a-P>0.95 ; b-P>0.99 ; c-P>0.999$.

In the second half of the experiment, the difference with the control in terms of live weight decreased, and in the group E1, which received feed with $45 \%$ replacement of soybeans with sunflower, significantly - up to $1.2-1.5 \%$ and amounted to only $17.6-23 \mathrm{~g}$. The decrease in the difference between the control and the group E2, which was fed food with $70 \%$ replacement of soybeans for sunflower, during this period, was insignificant - up to $8.7-20.3 \%$. Thus, the difference in live weight between the chickens of the groups E1 and $C$ at the end of rearing practically leveled off. At the same time, chickens of group E2 significantly $(P>0.999)$ exceeded them by this indicator by $375 \mathrm{~g}$. Similar results were obtained by Alagwany M. et al. [13], according to which the replacement of up to $50 \%$ of soybean meal with sunflower in the diet of broiler chickens led to an increase in their live weight by $8.1 \%$ and an improvement in feed conversion by $13.4 \%$ compared to the control.

It should be noted that the differences established by us in the live weight of the chickens of the experimental and control groups are due to the unequal growth rate of the chickens of these groups at different age periods, as evidenced by the indicators of the average daily and relative gain in live weight (table 4). 
4. Intensity of growth of live weight of chickens by rearing periods when using protein sunflower concentrate in the diet

\begin{tabular}{|l|c|c|c|}
\hline \multirow{2}{*}{$\begin{array}{l}\text { Live weight gain during the } \\
\text { rearing period }\end{array}$} & \multicolumn{3}{|c|}{ Poultry group depending on the level of soybean substitution PSC } \\
\cline { 2 - 4 } & C (0\%) & E1 (45\%) & E2 (70\%) \\
\hline Absolute, g & 336.5 & 379.4 & 417.8 \\
\hline Average daily, g & 24.0 & 27.1 & 29.8 \\
\hline Relative, \% & 153.3 & 157.8 & 160.8 \\
\hline & \multicolumn{3}{|c|}{ For 28 days } \\
\hline Absolute, g & 1098.9 & 1117.0 & 1199.0 \\
\hline Average daily, g & 39.2 & 39.9 & 42.8 \\
\hline Relative, \% & 182.9 & 183.3 & 184.4 \\
\hline & & For 42 days \\
\hline Absolute, g & 1795.6 & 1819.1 & 2171.0 \\
\hline Average daily, g & 42.8 & 43.3 & 51.7 \\
\hline Relative, \% & 189.2 & 189.4 & 191.0 \\
\hline
\end{tabular}

The average daily gain in live weight during the entire growing period was high in chickens of the group E2, with a $70 \%$ level of replacement of soy components with sunflower concentrate in the diet, according to the results of the experiment it was $51.7 \mathrm{~g}$, which is $20.9 \%$ higher than in the control, where sunflower was not added to the diet. Chickens of the group E1, which received a diet with $45 \%$ replacement of soybeans with sunflower, at the beginning of growing, occupied an intermediate position in this indicator. On the fourth week in this group, a decrease in the intensity of growth of chickens was observed, when an insignificant advantage of the average daily increase in their live weight over the control was recorded (by $0.7 \mathrm{~g}$ ), and by the end of rearing, the average daily increase in chickens from the group E1 was practically equal to that of the control.

The study of the relative growth rate of poultry live weight showed that the amplitude of intergroup fluctuations was not high - from 4.5 to $7.5 \%$ in 14 days of growing, from 0.4 to $1.4 \%$ in 28 days and from 0.2 up to $1.8 \%$ for the entire period. In general, for the period of feeding the experimental chickens, this indicator ranged from 189.2 to $191.0 \%$ with a slight difference between the groups.

Since chickens of all groups ate almost the same amount of feed (feed costs per head did not differ significantly and amounted to $3.41-3.49 \mathrm{~kg}$ ), and the increase in live weight was higher in the group E2, then feed costs per $1 \mathrm{~kg}$ of increase in it turned out to be lower at the beginning of the experiment (14 days) by $17 \%$, at the end - by $15.3 \%$ (Figure).

The feed conversion for 42 days by chickens fed with the replacement of soy components with sunflower concentrate at the level of $70 \%$ was $1.61 \mathrm{~kg}$. In the group E1, whose chickens consumed feed with $45 \%$ replacement of soybeans with sunflower, there was a slight decrease in feed costs per $1 \mathrm{~kg}$ of live weight gain compared to the control - by $1 \%(1.89 \mathrm{~kg}$ versus $1.90 \mathrm{~kg})$. That is, replacing soybeans with protein sunflower concentrate improved feed conversion in chickens. 


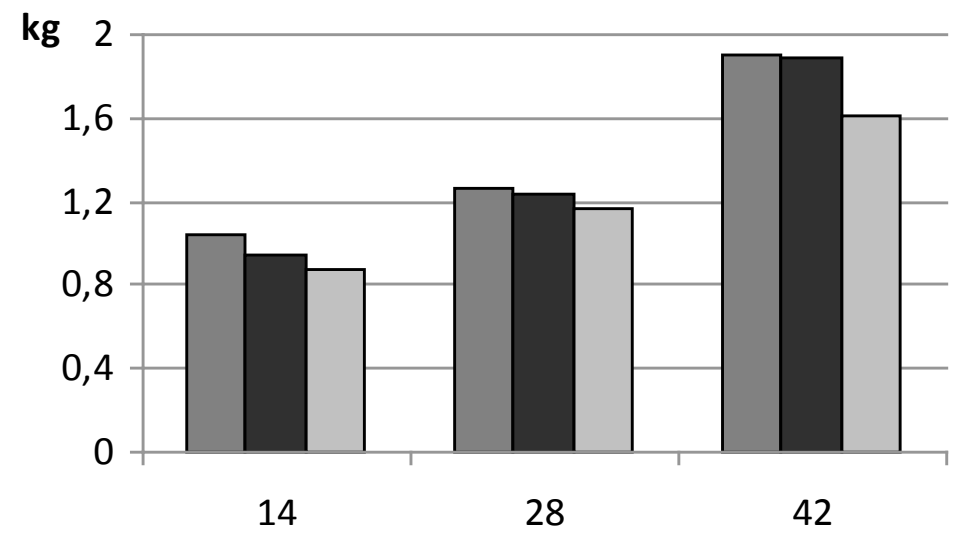

Chick age

Feed costs per $1 \mathrm{~kg}$ of increase in live weight of chickens when using different rations, $\mathrm{kg}$ : $\square$ - control (without sunflower); $\square$-E1 (45\% replacement of soybeans with sunflower); - experiment 2 (70\% replacement of soybeans with sunflower)

At the end of the fattening period at 42 days of age, all poultry in groups were slaughtered. The results of the analysis of meat qualities of chickens are determined (Table 5). The yield of gutted carcasses in the control and the group E1 was the same 67.6-67.7\%, while in the group E2, which received feed with $70 \%$ replacement of soybeans with protein sunflower concentrate this figure was $5.5 \%$ higher.

\section{Slaughter qualities of broiler chickens when using protein sunflower concentrate in the diet}

\begin{tabular}{|l|c|c|c|}
\hline \multirow{2}{*}{ Indicators } & \multicolumn{3}{|c|}{ Poultry group depending on the level of soybean substitution PSC } \\
\cline { 2 - 4 } & $\mathrm{C}(0 \%)$ & $\mathrm{E} 1(45 \%)$ & E2 $(70 \%)$ \\
\hline Pre-slaughter weight, g & $1841.6 \pm 44.54$ & $1855.0 \pm 36.81$ & $2180.0 \pm 33.83$ \\
\hline Gutted carcass weight, g & $1246.3 \pm 43.63$ & $1256.6 \pm 38.04$ & $1595.0 \pm 50.51$ \\
\hline Gutted carcass yield,\% & 67.6 & 67.7 & 73.1 \\
\hline
\end{tabular}

To compare the effectiveness of feeding poultry with basic and experimental feeds, the EIMP was determined, which in the control is 227 , in the group E1 - 216.7, in the group E2 - 322.5 points. In the poultry industry, it is considered acceptable (the limit level) the value of this index is 300 points. With a calculated value of the EIMP equal to or exceeding 300 points, production is considered technologically efficient. As you can see, feeding broiler chickens turned out to be technologically effective when using an experimental feed with replacing soy components with protein sunflower concentrate at the level of $70 \%$, since in this group the EIMP is 322.5 , in the other two groups the feeding efficiency was significantly lower.

Thus, our studies confirm the economic efficiency of $70 \%$ replacement of soy components with protein sunflower concentrate in broiler diets. That is, taking into account productivity indicators (an increase in live weight and the intensity of its growth, an improvement in feed conversion, an increase in gutted carcass yield), it can be recommended to use compound feed in feeding broiler chickens with an appropriate level of replacement of soybeans with protein sunflower concentrate.

\section{Conclusions}

Sunflower by-products, in particular the protein sunflower concentrate we have studied with a crude protein content of $44 \%$ and higher, can be quite an acceptable feed ingredient for broiler chickens. Replacing it with soy components (cake and meal) in the diet of broiler chickens can reach $70 \%$, provided that additional lysine is added. Chickens that consumed feed with $70 \%$ replacement of soy components with sunflower concentrate showed high safety (98\%), an increase in live weight by $20.3 \%$ and the intensity of its growth by $20.9 \%$, an improvement in feed conversion by $15.3 \%$, an increase in the yield of gutted carcasses by $5.5 \%$ compared with poultry, the diet of which contained only soy components. The European index of meat productivity of 322.5 points indicates that the use of protein sunflower concentrate instead of soy components at the level of $70 \%$ in the broiler chicken ration is technologically effective. 


\section{References}

1. Senkoylu, N., \& Dale, N. (1999). Sunflower meal in poultry diets: a review. World's Poultry Science Journal, 55(2), 153-174. doi: 10.1079/wps19990011

2. Boiarchuk S.V. (2013). Enerhetychna pozhyvnist bilkovykh kormiv dlia kurchat-broileriv. [Energy nutritional value of protein feed for broiler chickens]. Modern poultry, 5, 20-27. [In Ukrainian].

3. Alagawany, M., Farag, M. R., El-Hack, M. E. A., \& Dhama, K. (2015). The Practical Application of Sunflower Meal in Poultry Nutrition. Advances in Animal and Veterinary Sciences, 3(12), 634-648. doi: 10.14737/journal.aavs/2015/3.12.634.648

4. Sredanovic, S., Levic, J., \& Đuragic, O. (2011). Upgrade of sunflower meal processing technology. Helia, 34(54), 139-146. doi: 10.2298/hel1154139s

5. Kuzmenko, L. M. (2013). Efektyvnist kombikormiv z soniashnykovym shrotom pidvyshchenoi kormovoi tsinnosti ta riznoiu strukturoiu zernovoi hrupy u hodivli molodniaku svynei. [The effectiveness of highly nourishing sunflower meal and forage of different composition of crops in feeding growing-fishing pigs]. Pig Breeding. The interdepartmental subject scientific digest, 62, 176181. [In Ukrainian].

6. Zagorakis, K., Liamadis, D., Milis, Ch., Dotas, V., \& Dotas, D. (2018). Effects of replacing soybean meal with alternative sources of protein on nutrient digestibility and energy value of sheep diets. South African Journal of Animal Science, 48(3), 489. doi: 10.4314/sajas.v48i3.9

7. Ditta, Y. A., \& King, A. J. (2017). Recent advances in sunflower seed meal as an alternate source of protein in broilers. World's Poultry Science Journal, 73(3), 527-542. doi: $10.1017 / \mathrm{s} 0043933917000423$

8. Baghban-Kanani, P., Hosseintabar-Ghasemabad, B., Azimi-Youvalari, S., Seidavi, A., Ayaşan, T., Laudadio, V., \& Tufarelli, V. (2018). Effect of different levels of sunflower meal and multi-enzyme complex on performance, biochemical parameters and antioxidant status of laying hens. South African Journal of Animal Science, 48(2), 390. doi: 10.4314/sajas.v48i2.20

9. Jankowski, J., Lecewicz, A., Zdunczyk, Z., Juskiewicz, J., \& Slominski, B. A. (2011). The effect of partial replacement of soyabean meal with sunflower meal on ileal adaptation, nutrient utilisation and growth performance of young turkeys. British Poultry Science, 52(4), 456-465. doi: 10.1080/00071668.2011.602664

10. Vetési, M., Mezes, M., \& Kiss, L. (1998). Using sunflower meal in waterfowl diets. Archiv fur Geflugelkunde, 62(1), 7-10.

11. Sangsoponjit, S., Suphalucksana, W., \& Srikijkasemwat, K. (2017). Effect of feeding sunflower meal on the performance and carcass characteristics of broiler chickens. Chemical Engineering Transactions, 58, 841-846. doi: 10.3303/CET1758141.

12. Alagawany, M., Attia, A. I., Ibrahim, Z. A., Mahmoud, R. A., \& El-Sayed, S. A. (2017). The effectiveness of dietary sunflower meal and exogenous enzyme on growth, digestive enzymes, carcass traits, and blood chemistry of broilers. Environmental Science and Pollution Research, 24(13), 12319-12327. doi: 10.1007/s11356-017-8934-4.

13. The influences of feeding broilers on graded inclusion of sunflower meal with or without Avizyme on growth, protein and energy efficiency, carcass traits, and nutrient digestibility. (2018). Turkish Journal of Veterinary and Animal Sciences, 42(3). doi: 10.3906/vet-1612-85.

14. Waititu, S. M., Sanjayan, N., Hossain, M. M., Leterme, P., \& Nyachoti, C. M. (2018). Improvement of the nutritional value of high-protein sunflower meal for broiler chickens using multi-enzyme mixtures. Poultry Science, 97(4), 1245-1252. doi: 10.3382/ps/pex418.

15. Alagawany, M., Attia, A.I., Ibrahim, Z.A., \& Mahmoud, R.A. (2017). Impact of Dietary Sunflower Meal on Performance, Blood Parameters and Nutrient Digestibility in Broilers Chickens. International Journal of Animal Science, 1(2), 1007-1011. 